\title{
ЗАСТОСУВАННЯ МЕТОДІВ ФІЗИЧНОЇ РЕАБІЛІТАЦІЇ У ДІТЕЙ ІЗ СИНДРОМОМ РУХОВИХ ПОРУШЕНЬ
}

\author{
М. В. Віцентович, Т. Г. Бакалюк, Г. О. Стельмах \\ Тернопільський національний медичний університет \\ імені І. Я. Горбачевського МОЗ Украӥни
}

\begin{abstract}
Стаття присвячена аналізу застосування методів фізичної реабілітації у дітей із синдромом рухових порушень. Отримані дані показують, що на сьогодні застосовують велику кількість реабілітаційних підходів при цьому синдромі, а також використовують методи фізичної реабілітація, які позитивно впливають на відновлення рухових функцій у дітей з ураженням центральної нервової системи, особливо при проведенні ранньої реабілітації.
\end{abstract}

\section{APPLICATION OF PHYSICAL REHABILITATION METHODS IN CHILDREN WITH MOVEMENT DISORDERS SYNDROME}

\author{
M. V. Vicentovich, T. H. Bakaliuk, H. O. Stelmakh \\ I. Horbachevsky Ternopil National Medical University
}

\begin{abstract}
The article is devoted to the analysis of the application of methods of physical rehabilitation in children with motor skills disorder. The obtained data show that today a large number of rehabilitation approaches are applied to this syndrome and the use of physical rehabilitation methods has a positive effect on the restoration of the motor functions of children with lesions of the central nervous system, especially during early rehabilitation.
\end{abstract}

Вступ. В Україні спостерігають тенденцію до зростання кількості дітей із захворюваннями, які супроводжуються синдромом рухових порушень [2]. Одним із найпоширенішим рухових розладів дитячого віку є дитячий церебральний параліч (ДЦП), який спостерігають з частотою від 2 до 3,3 на 1000 новонароджених [10].

Рухові порушення зумовлені різними негативними чинниками, що впливали на нервову систему дитини під час внутрішньоутробного розвитку, народження та впродовж перших місяців чи років життя [2]. Саме рухова активність малюка - це один з основних чинників, за яким прийнято оцінювати стан його здоров'я. Синдром рухових порушень діагностують у випадку, коли у немовлят спостерігають зниження або підвищення рухової активності, м'язову дистонію та ослаблення м'язової сили. Найбільш схильні до нього малюки віком від 3 до 7 місяців [3].

Незважаючи на високий рівень сучасних діагностичних технологій, багато аспектів церебральних

(c) М. В. Віцентович, Т. Г. Бакалюк, Г. О. Стельмах, 2020 уражень у плода і дітей раннього віку залишаються невиявленими $[2,6]$. Оскільки гіпоксично-ішемічне ураження центральної нервової системи може бути причиною довготривалих неврологічних ускладнень та інвалідності дітей $[5,6]$, застосування реабілітаційних втручань заслуговує особливої уваги.

Основна частина. Проаналізовано дані науковометодичної літератури та клінічні дослідження, які стосуються проблеми організації програми ранньої фізичної реабілітації дітей із синдромом рухових порушень.

Типовим наслідком ураження центральної нервової системи є порушення психомоторного розвитку дитини різного ступеня тяжкості - від мінімальних мозкових дисфункцій до ДЦП з формуванням тяжкої інвалідності $[3,5]$.

Загальні симптоми захворювання: патологічні пози, які приймає дитина; згинає і розгинає ніжки і ручки з труднощами; монотонний плач малюка; дитина погано набирає масу тіла та зригує; скутість малюка; значне запізнення слухових і зорових реакцій. 
Малюк відстає у фізичному розвитку, йому складніше навчитися перевертатися, сідати, тримати рівновагу і так далі [5].

Упродовж останнього часу відзначають активізацію впровадження нових підходів та методів фізичної реабілітації у дітей з ураженням центральної нервової системи на першому році життя [6].

Одним із найважливіших методів фізичної реабілітації пацієнтів із ДЦП є лікувальна фізична культура (ЛФК), яку розчинають вже в перші місяці життя дитини, відразу після встановлення діагнозу. При цьому застосовують комплекси вправ, які запобігають ослабленню і атрофії м'язів, розвитку контрактур і сприяють моторному розвитку дитини [7].

Останнім часом з'являється багато наукових робіт про нові методи лікування ДЦП. Численні дослідження вказують на ефективність методу (constraint-induced movement therapy) [9], який стимулює компенсаторну функцію нервової системи. Немає єдиної думки щодо поліпшення рухових функцій в результаті тренування м'язової сили у пацієнтів із ДЦП [1, 2, 6, 7].

Широко застосовують методи нейророзвиваючого підходу Бобат [11], терапії Войта [13], кондуктивної педагогіки Петьо [12], динамічної пропріоцептивної корекції К. А. Семенової [4, 8]. Але ефективність цих методів все ще не обґрунтована з точки зору доказової медицини.

Оскільки кожен пацієнт є особливим, існування єдиного універсального методу реабілітації $\epsilon$ неможливим. На жаль, застосування лише традиційних методів терапії далеко не у всіх випадках дозволяє досягти бажаних результатів. Тільки поєднання лікувальних впливів різних модальностей може забезпечити бажаний результат.

Одним із таких багатокомпонентних методів реабілітації пацієнтів з ДцП є система інтенсивної нейрофізіологічної реабілітації, відома під назвою «Метод Козявкіна». Шляхом стимуляції компенсаторних можливостей дитячого організму і активації нейропластичності ця система створює в організмі дитини новий функціональний стан, який відкриває нові можливості для стимуляції моторного та психічного розвитку дитини. Різнобічні лікувальні впливи цього методу, які взаємно доповнюють і підсилюють один одного, спрямовані на досягнення основної мети реабілітації - поліпшення якості життя пацієнтів [1].

На основі попереднього аналізу і систематизації зроблена спроба розробки універсальної генеральної стратегії корекції для подолання рухових пору- шень у дітей зазначеного контингенту [6]. Розроблена стратегія передбачає послідовну реалізацію ряду корекційних векторів. Початковим визнаний вектор релаксації, релізу, подолання рестрикцій, що створить необхідний фон для старту корекційних заходів. Наступним був визнаний корекційний вектор вивільнення необхідних ступенів свободи в опорноруховій системі підопічних. Третій корекційний вектор представлений напрямком гармонізації м'язовофасціальної системи, досягненням належного балансу між м'язами-антагоністами, згиначами і розгиначами. Четвертий корекційний вектор повинен відповідати за управління глобальними і локальними рухами на основі вдосконалення міжпівкульних нейронних координацій. Кожен з представлених стратегічних векторів складається з окремих технік, методик, процедур, прийомів, які будуть в подальшому реалізовані в корекційній програмі.

Фізична реабілітація включає як активні, так і пасивні методи у вигляді гідротерапії, механотерапії, масажу, мануальної терапії. П. В. Кравцевич і співавт. наводять результати дослідження, які показують необхідність використання лікувального плавання в комплексі з фіксаційним масажем і онтогенетичною гімнастикою в якості нового ефективного способу впливу на організм дитини зі спастичними формами ДЦП з метою відновлення рухових здібностей в умовах навчально-реабілітаційного процесу [9]. Ця методика дозволяє також активізувати всі показники системи зовнішнього дихання у дітей з ДЦП.

Незважаючи на те, що застосовують велику кількість методів фізичної реабілітації для дітей із синдромом розладу рухових функцій, існує відчутна потреба комплексного дослідження особливостей корекції дітей даного контингенту та впровадження саме ранньої програми реабілітації. Гіпотеза про результативність ґрунтується на тому, що саме раннє застосування комплексної програми фізичної реабілітації дітей раннього віку з різним ступенем тяжкості захворювання забезпечує високу ефективність у напрямі відновлення рухових функцій.

Висновки. Аналіз літературних джерел за даною проблемою дав можливість зрозуміти, що застосування методів фізичної реабілітації позитивно впливає на відновлення рухових функцій дітей $з$ ураженням центральної нервової системи, запобігає розвитку вторинних ортопедичних та інших ускладнень, допомагає кращому інтелектуальному та психологічному розвитку. 


\section{СПИСОК ЛІТЕРАТУРИ}

1. Динамика показателей моторного развития детей с церебральными параличами в процессе реабилитации по методу профессора Козявкина / В. И. Козявкин, В. И. Лисович, А. Д. Кушнир, О. А. Качмар // Международный неврологический журнал. - 2018. № 8 (102). - С. 14-22.

2. Мартиненко Я. А. Раннє втручання у дітей з руховими порушеннями / Я. А. Мартиненко // Міжнародний неврологічний журнал. - 2016. - № 2 (80). - С. 168-169.

3. Мартинюк В. Ю. Діагностичні критерії рухових порушень у немовлят із позиції доказової медицини / В. Ю. Мартинюк, О. В. Назар // Міжнародний неврологічний журнал. - 2014. - № 3 (65). - С. 164-165.

4. Семенова К. А. Метод динамической проприоцептивной коррекции в восстановительном лечении больных детским церебральным параличом / К. А. Семенова, А. А. Воронов, Н. Ю. Титаренко // Детская и подростковая реабилитация. - 2004. - № 2. - С. 45-48.

5. Мога Н. Д. Дифференциальные подходы к классифицированию спастических двигательных нарушений у детей / Н. Д. Мога // Науковий часопис. - 2018. - № 35. C. 50-61.

6. Мога М. Д. Корекційна стратегія в фізичному вихованні дітей раннього віку зі спастичним типом рухових порушень / М. Д. Мога // Актуальні питання корекційної освіти (педагогічні науки). - 2012. - № 14. - С. 228-238.

7. Непосредственные и отдаленные результаты комплексной реабилитации больных детским церебральным параличом в виде спастической диплегии / А. В. Рогов, Е. Ф. Левицкий, В. К. Пашков [и др.] // Вестник Ивановской медицинской академии. - 2014. - № 19 (2). - С. 19-23.

8. Семенова К. А. Проблема восстановительного лечения детского церебрального паралича / К. А. Семенова // Журнал неврологии и психиатрии. - 2012. - № 7. - С. 9-13.

9. Сравнительная характеристика влияния различных средств восстановления на функцию внешнего дыхания у детей с детским церебральным параличом / П. В. Кравцевич, А. А. Бруйков, А. В. Гулин, А. И. Петкевич // Вестник Тамбовского университета. - 2013. - № 18 (4). C. 1362-1364.

10. Заклади охорони здоров'я та захворюваність населення України у 2018 році : статистичний бюлетень // Держкомстат України. - К., 2019. - 36 с.

11. Butler C. Effects of neurodevelopmental treatment (NDT) for cerebral palsy: an AACPDM evidence report / C. Butler, J. Darrah // Developmental medicine and child neurology. - 2001. - Vol. 43 (11). - P. 778-790.

12. Reddihough D. S. Efficacy of programmes based on conductive education for young children with cerebral palsy / D. S. Reddihough // Developmental Medicine \& Child Neurology. - 1998. - Vol. 40 (11). - P. 763-770.

13. Vojta $V$. The basic elements of treatment according to Vojta / V. Vojta // Management of the Motor Disorders of Children with Cerebral Palsy. - 1984. - Vol. 75

Отримано 23.03.20 